\title{
Efektivitas Pembelajaran Mata Kuliah Manajemen Usaha Kecil pada Program Studi Pendidikan Administrasi Perkantoran FIS UNM
}

\section{Learning Effectiveness of Small Business Management Courses at UNM Office Administration Education Departement, FIS UNM}

\author{
Sabahuddin $^{1}$, Risma Niswaty ${ }^{2}$, Muhammad Darwis ${ }^{2}$. \\ ${ }_{1,2,3}$ Universitas Negeri Makassar
}

\begin{abstract}
Penelitian ini bertujuan untuk mengetahui efektifitas Pengajaran Mata Kuliah Manajemen Usaha Kecil Pada Program Studi Pendidikan Administrasi Perkantoran Fakultas Ilmu Sosial Universitas Negeri Makassar. Penelitian ini bersifat deskripsi kuantitatif dengan populasi penelitian ini adalah seluruh mahasiswa Program Studi Pendididkan Administrasi Perkantoran angkatan 2012, 2013 dan 2014 berjumlah keseluruhan 234 orang. Penarikan sampel sebanyak 70 orang dan penarikan sampel secara Probability Sampling dengan tehnik Simple Random Sampling. Untuk mencapai tujuan tersebut maka peneliti menggunakan teknik pengumpulan data melalui observasi, angket dan dokumentasi. Data yang dikumpulkan disajikan melalui tabel frekuensi dan diolah melalui teknik perhitungan skor. Hasil penelitian menunjukkan bahwa Efektivitas Pembelajaran Mata Kuliah Manajemen Usaha Kecil Pada Program Studi Pendidikan Administrasi Perkantoran FIS UNM efektif, dengan menggunakan indikator : (1) Tujuan pembelajaran, (2) Dosen, (3) Mahasiswa, (4) Materi pelajaran, (5) Metode, (6) Alat, (7) Evaluasi.
\end{abstract}

Kata kunci : Efektivitas, manajemen usaha kecil, pembelajaran

\begin{abstract}
This study aims to determine the effectiveness of Teaching Small Business Management Courses at the Office of Education Administration Study Program at the Faculty of Social Sciences, Makassar State University. This research is a quantitative description with the population of this study is that all students of the 2012, 2013 and 2014 Office Administration Education Programs, 234 people. Sampling of 70 people and Probability Sampling with Simple Random Sampling technique. To achieve these objectives, the researcher uses data collection techniques through observation, questionnaires and documentation. The collected data is presented through a frequency table and processed through a score calculation technique. The results of the study showed that the Learning Effectiveness of Small Business Management Courses in the Office of Administrative Studies at FIS UNM Office was effective, using indicators: (1) Learning objectives, (2) Lecturers, (3) Students, (4) Study material, (5) Methods, (6) Tools, (7) Evaluation.
\end{abstract}

Keywords: effectiveness, small business management, learning 


\section{PENDAHULUAN}

Pendidikan dalam sejarah peradaban manusia adalah komponen penting yang erat dan tidak terpisahkan dari perjalanan hidup manusia. Kualitas sebuah bangsa dan peradaban ditentukan oleh kualitas (Jimenez, Nguyen, \& Patrinos, 2013; Neamtu, 2015; Winters, 2011) Pendidikan menjadi bagian penting sebab dengan pendidikan manusia mampu mengembangkan nalar berpikirnya sekaligus meningkatkan taraf hidup dan kemampuan teknis atau pun nonteknis lainnya.

Peranan pendidikan yang lebih baik adalah bagian sentral dari sebagian besar strategi pembangunan termasuk pembangunan di bidang ekonomi (Curea \& Ciora, 2013; Fallis, 2013; E. A. Hanushek \& Woessmann, 2007; E. a Hanushek, 2007). Keterbelakangan edukasi seringkali menjadi hambatan serius dalam proses pembangunan masyarakat. Sebaliknya, dengan tingginya kualitas pendidikan suatu negara, maka proses pembangunan masyarakatnya akan berjalan cepat dan signifikan. Pendidikan yang digalakkan sangat berperan dalam menentukan kelangsungan pembangunan nasional, dimana pendidikan tersebut dapat melahirkan generasi baru yang kreatif, mandiri, serta berkualitas. Oleh karena itu, sebagai generasi pelanjut, sangat membutuhkan bimbingan, pemahaman dan dorongan dalam rangka melanjutkan segala usaha yang telah dilakukan oleh terdahulu.

Dunia pendidikan bila dihubungkan dengan tuntutan lapangan kerja selalu menjadi masalah yang kompleks, sebab pendidikan itu berjalan menurut dinamikanya, sementara lapangan kerja menghendaki perubahan maupun keterampilan. Oleh karena itu, pendidikan mempunyai arti besar dalam upaya meningkatkan mutu pendidikan.

Salah satu solusi yang ditawarkan pemerintah untuk mengurangi angka pengangguran adalah menciptakan lapangan kerja yang bersifat padat karya. Namun, kalangan terdidik cenderung menghindari pilihan pekerjaan ini karena preferensi mereka terhadap pekerjaan kantor lebih tinggi. Preferensi yang lebih tinggi didasarkan pada perhitungan biaya yang telah mereka keluarkan selama menempuh pendidikan dan mengharapkan tingkat pengembalian yang seimbang.

Berbagai kegiatan usaha berjalan sesuai dengan kondisi potensi masing - masing perubahan dan bisa di kategorikan tiga kelompok, yaitu perusahaan/ bisnis skala besar atau raksasa, skala menegah dan skala kecil (Yasin, 2015). Pada lingkup perguruan tinggi, manajemen usaha kecil sering diajarkan dalam proses perkuliahan dan bahkan dijadikan mata kuliah wajib dalam proses akademik. Hal ini menunjukkan kesadaran akan pentingnya ilmu manajemen usaha kecil. Manajemen usaha kecil juga dijadikan suatu media untuk mengembangkan kreativitas mahasiswa dalam berkarya dan menghasilkan suatu usaha yang bermanfaat dan berguna di masa depan. Hal ini dibuktikan dengan adanya mahasiswa yang mampu menciptakan usaha-usaha baru yang berdasar dari keterampilan mempelajari mata kuliah manajemen usaha kecil.

Pengetahuan dan pemahaman tentang manajemen usaha kecil yang semakin luas, membuat mahasiswa untuk lebih memperdalam lagi pengetahuan dan keterampilannya. Seorang mahasiswa harus sadar akan pentingnya suatu pengetahuan yang merupakan bekal untuk memasuki dunia kerja. Pemanfaatan usaha-usaha baru oleh mahasiswa dapat mengembangkan pengetahuan dan keterampilan yang dimiliki sehingga mereka mampu bersaing melalui 
Sabahuddin, Risma Niswaty, Muhammad Darwis; Efektivitas Pembelajaran Mata Kuliah .... $\mid 129$

pengetahuan dan keterampilan yang di dapat dari bangku perkuliahan ketika memasuki dunia kerja.

Pengetahuan manajemen usaha kecil yang diharapkan dalam proses perkuliahan, bukan sekedar mengetahui arti dan makna manajemen usaha kecil itu sendiri melainkan mahasiswa diharapkan mampu mengembangkan keterampilan dan keahlian yang menyangkut dengan tujuan pembelajaran mata kuliah tersebut. Berdasarkan pengamatan peneliti pada mahasiswa yang telah mempelajari mata kuliah menejemen usaha kecil, masih adanya berapa mahasiswa yang belum mengembangkan dan mengaplikasikannya di luar perkuliahan dari ilmu yang diperoleh.

\section{METODE}

Jenis Penelitian yang digunakan dalam penelitian ini adalah penelitian deskripsi Kuantitatif. Penelitian deskripsi kuantitatif dipilih karena sesuai dalam proses pengumpulan data yang berkaitan dengan efektifitas Pembelajaran mata kuliah manajemen usaha kecil pada program studi pendidikan administrasi perkantoran FIS UNM. Dalam penelitian ini teknik pengumpulan data yang digunakan adalah teknik observasi, angket, dan dokumentasi. Penarikan sampel secara probability sampling dengan teknik simple random sampling. Data yang dikumpulkan disajikan melalui tabel frekuensi dan diolah melalui teknik perhitungan skor.

\section{HASIL PENELITIAN DAN PEMBAHASAN}

Penelitian ini membahas mengenai keefektifan pembelajaran mata kuliah manajemen usaha kecil pada program studi pendidikan administrasi perkantoran fakultas ilmu sosial universitas negeri makassar dengan indikator sebagai berikut : tujuan pembelajaran, dosen, mahasiswa, materi pelajaran, metode pembelajaran, alat dan evaluasi.

\section{Tujuan Pembelajaran}

Berdasarkan indikator tujuan pembelajaran terkait Efektivitas Pembelajaran Mata Kuliah Manajemen Usaha Kecil Pada Program Studi Pendidikan Administrasi Perkantoran Fakultas Ilmu Sosial Universitas Negeri Makassar yang berada pada kategori tinggi. Hal ini dikarenaka karena minat yang tinggi dari para mahasiswa untuk mempelajari mata ku kuliat tersebut. Selain itu penguasaan dan pemahaman materi, substansi dan metodologi dasar keilmuan MUK juga terbilang bagus. Pencapaian ini tidak terlepas dari pemberian teori oleh dosen sebelum melakukan praktek kepada mahasiswa yang didukung oleh pemberian pengarahan ataupun petunjuk pelaksananan sebelum praktek. Hal ini, dapat memungkinkan mahasiswa untuk memahami teori dalam pengaplikasiannya pada praktek kedepannya.

\section{Dosen}

Berdasarkan indikator dosen pada Efektivitas Pembelajaran Mata Kuliah Manajemen Usaha Kecil Pada Program Studi Pendidikan Administrasi Perkantoran Fakultas Ilmu Sosial Universitas Negeri Makassar yang berada pada kategori tinggi. Selain tujuan pembelajaran, indikator dosen juga memiliki peran yang tidak kalah pentingnya. Hal ini, dapat kita lihat dari kemapuan dosen untuk menyeimbangkan antara teori dan praktek dalam penyajian materi 
130| Jurnal Office, Vol.3, No.2, 2017

perkuliahan pada proses perkuliahan. Sehingga mahasiswa diharapkan mampu untuk memahami materi perkuliahan tidak hanya secara teori tapi juga pengaplikasian teori pada prakteknya. Sehingga, kecendrungan dosen memberikan tugas praktek dalam kelas menjadi salah satu cara untuk membantu mahasiswa dalam memahami materi ajar yang diberikan.

\section{Mahasiswa}

Berdasarkan indikator mahasiswa pada penilaian Efektivitas Pembelajaran Mata Kuliah Manajemen Usaha Kecil Pada Program Studi Pendidikan Administrasi Perkantoran Fakultas Ilmu Sosial Universitas Negeri Makassar yang berada pada kategori tinggi. Hal ini, menjelaskan bahwa mahasiswa sebagai target dari tujuan pembelajaran juga telah mampu memahami materi pembelajaran yang diajarkan dosen dengan baik dengan adanya penerapan pengetahuan, keterampilan dan sikap dalam kehidupan sehari-hari, yang dimana ditunjang dengan tingginya motivasi mahasiswa dalam mempelajari mata kuliah manajemen usaha kecil.

\section{Materi Pembelajaran}

Berdasarkan indikator materi pembelajaran pada Efektivitas Pembelajaran Mata Kuliah Manajemen Usaha Kecil Pada Program Studi Pendidikan Administrasi Perkantoran Fakultas Ilmu Sosial Universitas Negeri Makassar yang berada pada kategori tinggi. Pencapaian ini tidak lepas dari penyesuaian materi perkuliahan dengan tujuan pembelajaran dan kompetensi yang harus dikuasai. Hal ini,juga tentunya telah disesuaikan dengan referensi buku yang telah direkomendasikan oleh dosen sebagai bahan rujukan untuk pemahaman materi yang disampaikan pada proses belajar mengajar. Sehingga dapat memudahkan mahasiswa untuk memahami materi pembelajaran tersebut. Dengan adanya penyeimbangan materi perkuliahan dengan waktu yang telah ditentukan.

\section{Metode Pembelajaran}

Berdasarkan indikator metode pembelajaran yang digunakan pada Efektivitas Pembelajaran Mata Kuliah Manajemen Usaha Kecil Pada Program Studi Pendidikan Administrasi Perkantoran Fakultas Ilmu Sosial Universitas Negeri Makassar yang berada pada kategori tinggi. Dapat disimpulkan bahwa, keberhasilan pencapaian tujuan pembelajaran tidak dapat dipisahkan pada metode pembelajaran yang digunakan oleh dosen dalam penyampaian materi ajar. Oleh karena itu terkadang dosen menggunakan beberapa metode pembelajaran yang dapat menunjang kegiatan proses belajar mengajar yang pastinya telah disesuaikan dengan bahan yang diajarkan.

Alat

Berdasarkan indikator alat yang digunakan pada Efektivitas Pembelajaran Mata Kuliah Manajemen Usaha Kecil Pada Program Studi Pendidikan Administrasi Perkantoran Fakultas Ilmu Sosial Universitas Negeri Makassar yang berada pada kategori tinggi. Alat pembelajaran juga memegang peran yang cukup penting dalam proses belajar mengajar karena dengan adanya alat pembelajaran dapat menunjang suasana belajar yang lebih kondusif dan dapat menstimulus mahasiswa untuk lebih aktif dan berpartisipasi dalam kegiatan pembelajaran. Selain itu dengan bantuan alat pembelajaran dapat membantu dosen untuk menyampaikan materi ajar yang akan dijelaskan pada mata kuliah manajemen usaha kecil. 
Sabahuddin, Risma Niswaty, Muhammad Darwis; Efektivitas Pembelajaran Mata Kuliah .... 131

\section{Evaluasi}

Berdasarkan indikator evaluasi yang digunakan pada Efektivitas Pembelajaran Mata Kuliah Manajemen Usaha Kecil Pada Program Studi Pendidikan Administrasi Perkantoran Fakultas Ilmu Sosial Universitas Negeri Makassar yang berada pada kategori tinggi. Pemberian latihan maupun tugas kepada mahasiswa baik itu pada saat proses belajar mengajat maupun pada akhir kegiatan pembelajaran juga tidak kalah pentingnya. Hal ini dikarenakan dengan adanya pemberian latihan maupun tugas kepada mahasiswa, dosen dapat mengetahui sejauh mana pemahaman mahasiswa terhadap materi yang diajarkan sehingga tujuan pembelajaran yang telah ditetapkan sebelumnya dapat tercapai.

\section{SIMPULAN}

Efektifitas Pengajaran Mata Kuliah Manajemen Usaha Kecil Pada Program Studi Pendidikan Administrasi Perkantoran Fakultas Ilmu Sosial Universitas Negeri Makassar pada kategori tinggi dengan indikator sebagai berikut : Tujuan Pembelajaran, Dosen, Mahasiswa, Materi Pelajaran, Metode Pembelajaran, Alat dan Evaluasi. Secara garis besar dari hasil penelitian dapat disimpulkan bahwa Efektivitas Pembelajaran Mata Kuliah Manajemen Usaha Kecil Pada Program Studi Pendidikan Administrasi Perkantoran Fakultas Ilmu Sosial Universitas Negeri Makassar, efektif berdasarkan indikator-indikator yang digunakan oleh peneliti.

\section{DAFTAR PUSTAKA}

Ali, Muhammad. 1998. Strategi Penelitian Pendidikan. Bandung: Angkasa.

Arikunto, Suharsimi. 2000. Manajemen Penelitian Cetakan Kelima. Jakarta: Rineka Cipta.

Curea, Ş. C., \& Ciora, C. (2013). The impact of human capital on economic growth. Quality Access to Success.

Choliq, Abdul. 2014. Pengantar Manajemen. Yogyakarta: Ombak (Anggota Ikapi)

Djamarad, Syaiful Bahri, Azwan Zain. 1996. Strategi Belajar Mengajar.Jakarta : PT. Rineka Cipta.

Fallis, A. . (2013). The role of school improvement in economic development. Journal of Chemical Information and Modeling. https://doi.org/10.1017/CBO9781107415324.004

Fathurrohman, Pupuh \& Sutikno M.Sobry, 2007. Strategi Belajar Mengajar. Bandung : Refika Aditama.

Hamalik, Oemar. 2001. Proses Belajar Mengajar. Bandung : Bumi Akasara.

Handayaningrat, Soewarno. 1988. Pengantar Ilmu Administras.,Jakarta : Gunung Agung.

Hasibuan, Melayu S.P. 2002. Manajemen Sumber Daya Manusia. Jakarta: Bumi Aksara 
132 | Jurnal Office, Vol.3, No.2, 2017

Moekijat. 2000. Fungsi-fungsi Manajemen. Bandung : CV. Mandar Maju.

Hanushek, E. A., \& Woessmann, L. (2007). The Role Of Education Quality For Economic Growth. https://doi.org/10.1596/1813-9450-4122

Hanushek, E. a. (2007). The Role of Education Quality in Economic Growth The Role of School Improvement in Economic Development. World Bank Policy Research Working Paper. https://doi.org/10.2139/ssrn.960379

Jimenez, E., Nguyen, V. T., \& Patrinos, H. A. (2013). Human capital development and economic growth in Malaysia and Thailand: Stuck in the middle? In Human Capital Formation and Economic Growth in Asia and the Pacific. https://doi.org/10.4324/9780203778739

Neamtu, D. M. (2015). Education, the Economic Development Pillar. Procedia - Social and Behavioral Sciences. https://doi.org/10.1016/j.sbspro.2015.02.138

Pangewa, Maharuddin. 2010. Perencanaan Pembelajaran. Makassar: Badan Penerbit Universitas Negeri Makassar

Riduwan. 2004. Metode dan teknik menyusun tesis, cetakan pertama. Bandung: Alfabeta.

Riyanto, Yatim. 2009. Paradigma Baru Pembelajaran. Jakarta: Kencana Prenada media Group

Sahabuddin, 2007. Mengajar dan Belajar. Makassr : Badan Penerbit Universitas Negeri Makassar.

Strees, M.Richard. 1985. Efektivitas Organisasi. Jakarta : Erlangga.

Sugiyono. 2011. Metode Penelitian Administrasi. Bandung: Alfabeta.

Suryana.2013. Kewirausahaan Kiat dan Proses Menuju Sukses.Jakarta : Salemba Empat

Usman, Moh Uzer. 1995. Menjadi Guru Profesional. Bandung: PT Remaja Rosdakarya

Winters, J. V. (2011). Why are smart cities growing? who moves and who stays. Journal of Regional Science. https://doi.org/10.1111/j.1467-9787.2010.00693.x

Yasin, H. (2015). Upaya Strategis Pemberdayaan Ekonomi Masyarakat melalui Kelompok USAha Bersama (Kube). Jurnal Ilmiah Ilmu Administrasi Publik Universitas Negeri Makassar, 5(1). 